\title{
PENGARUH PENERAPAN SISTIM FULL DAY SCHOOL TERHADAP HASIL BELAJAR PAI DI SD INTEGRAL HIDAYATULLAH KOTA GORONTALO
}

\author{
${ }^{1}$ Rahmatullah Baderan, ${ }^{2}$ Muh. Arif \\ ${ }^{1}$ Mahasiswa Pascasarjana IAIN Sultan Amai Gorontalo \\ ${ }^{2}$ Institut Agama Islam Negeri Sultan Amai Gorontalo \\ email: rahmatbaderan@gmail.com
}

\begin{abstract}
Abstrak
Penelitian ini dilatar belakangi oleh pentingnya pemilihan sekolah yang baik bagi siswa. Sekolah tidak hanya memberikan pelajaran mengenai ilmu pengetahuan saja tampa ada pengaplikasiannya dalam kehidupan sehari-hari, salah satunya yaitu pelajaran Pendidikan Agama Islam yang dimana mengajarkan siswa untuk mengamalkan syariat Islam. Beraneka ragam sekolah yang dapat dipilih oleh orang tua siswa. SD Integral Hidayatullah Kota Barat salah satu sekolah yang menerapkan sistem berbeda dengan sekolah lainnya, yaitu sistem full day school. sekolah ini membantu dalam perkembangan pengetahuan serta ahlak siswa. Penelitian ini bertujuan untuk mengetahui bagaimana penerapan sistem Full Day School terhadap hasil belajar Pendidikan Agama Islam. Jenis penelitian kuantitatif dengan pendekatan Design Survey Korelasional. Populasi dalam penelitian ini adalah seluruh peserta didik di SD Integral Hidaytullah Kota Barat yang berjumlah 83 orang. Teknik pengumpulan data yang digunakan yaitu: Angket. Data yang terkumpul dianalisis dengan menggunakan "SPSS v 16.0 for windows". Berdaasarkan hasil penelitian dan pembahasan dengan menggunakan analisis data melalui program "SPSS v 16.0 for windows" diperoleh persamaan regresi linier $Y=18.197+0.715 x$. hal ini berarti bahwa penerapa Full Day School, maka akan memberikan pengaruh terhadap hasil belajar PAI peserta didik sebesar 0.715. Sedangkan dari hasil analisis koefisien determinasi menunjukan, bahwa adanya pengaruh yang signifikan antara penerapan Full Day School dengan hasil belajar PAI peserta didik yaitu tergolong pada rentang yang sedang dengan presentasi 48,4\%. Jadi, jika penerapan Full Day School mengalami peningkatan maka akan turut memepengaruhi hasil belajar PAI peserta didik. Dari hasil penelitian diatas, menjelaskan bahwa pentingnya penerapan Full Day School untuk meningkatkan hasil belajar PAI peserta didik. Dan melihat adanya pengaruh yang sedang antara penerapan Full Day School dengan hasil belajar PAI, disarankan kepada guru PAI untuk lebih memperhatikan dan menigkatkan penerapan Full Day School, agar mampu meningkatakan hasil belajar PAI menjadi lebih baik.
\end{abstract}

Kata Kunci: Full Day School, Hasil Belajar PAI 


\section{PENDAHULUAN}

Pendidikan adalah suatu yang universal dan berlangsung secara berkelanjutan dari generasi kegenerasi dimanapun di dunia ini. Upaya memanusiakan manusia yang manusia melalui pendidikan itu diselenggarakan sesuai dengan pandangan hidup dan dalam latar sosial-kebuadayaan setiap masyrakat tertentu, dan yang menjadi kajian saya adalah pendidikan formal.Di Indonesia, tujuan dan fungsi pendidikan nasional yang tertuang dalam UU No 20 Tahun 2003 tentang sisdiknas menyatakan bahwa pendidikan nasional berfungsi mengembangkan kemampuan dan membentuk watak serta peradaban bangsa, bertujuan untuk berkembangnya potensi peserta didik agar menjadi manusia yang beriman dan bertakwa kepada tuhan yang maha esa, berakhlak mulia, sehat, berilmu, cakap, kreatif , mandiri, dan menjadi warga negara yang demokratis serta bertanggung jawab. ${ }^{1}$

Kemajuan ilmu pengetahuan teknologi (IPTEK) yang semakin hari semakin cepat, hingga kebutuhan akan kualitas pendidikan yang dapat dirasakan semua pihak menyebabkan sistem pendidikan yang dijalankan selama ini kurang efektif jika diterapkan di zaman globalisasi saat ini. Sehingga diiperlukan suatu sistem pendidikan yang dapat memenuhi kebutuhan perkembangan peserta didik, meningkatan kualitas pendiddikan agama dan moral kepada peserta didik, serta mengoptimalkan perkembangan peserta didik. Kebutuhan akan sistem pendidikan yang berkualitas dapat dijawab dengan keberadaan Full Day School yang diharapakan dapat memenuhi kebutuhan perkembangan anak, mengajarkan agama dan moral kepada anak, dan mengoptimalkan perkembangan anak mereka. Jika dilihat dari makna dan pelaksanaannya, Full Day School sebagian waktunya digunakan untuk program pelajaran yang suasananya informal, tidak kaku, menyenangkan bagi siswa dan membutuhkan kreativitas dan inovasi dari guru. Metode pembelajaran Full Day School tidak selalu dilakukan di dalam kelas, namun siswa diberi kebebasan untuk memilih tempat belajar. Artinya siswa bisa belajar dimana saja seperti halaman, perpustakaan, laboratorium dan lain-lain.

Sistem pengajaran Full Day School yang tidak kaku atau monoton, bahkan menyenangkan-karena seorang guru di Full Day School dituntut untuk bersifat profesional, kreatif dan inovatif, sedangkan siswa diberi kebebasan dlam memilih tempat belajarnya. Hal yang mampu memikat para siswa adalah sekolah Full Day School ini sarat dengan permainannya, yang bertujuan agar proses belajar mengajar penuh dengan kegembiraan, permainan-permianan yang menarik bagi siswa untuk belajar, betah disekolah, dan mendapatkan nilai plus yang berbasis keislaman.

\section{METODE PENELITIAN}

\section{Pendekatan dan Jenis Penilitian}

Adapun pendekatan yang digunakan dalam penelitian ini adalah kuantitatif dengan design survei korelasioanl. Penelitian survei korelasional merupakan penelitian yang berfokus pada penafsiran kovariasi diantatara variabel yang muncul secara alami. Tujuan penelitian survei korelasional adalah untuk mengidentifikasi hubungan prediktif

\footnotetext{
${ }^{1}$ Daryanto dan Suyatri Darmiatun, Implementasi Pendidikan Karakter di Sekolah.
} (Yogyakarta, Gava Media, 2013), h. 44 
dengan menggunakan teknik korelasi atau teknik statistik yang canggih. ${ }^{2}$ Jenis penelitian ini adalah kuantitatif. Penelitian ini dimaksudkan untuk mengungkap hungungan faktor pengaruh pendekatan scintfic sebagai variabel bebas (X) atau yang mempengaruhi dan kualitas Pendidikan Agama Islam (Y) atau yang dipengaruhi.

\section{Lokasi Penelitian}

Penelitian dilaksanakan di SD Integral Hidayatullah Kota Barat.sekolah ini dipilih didasarkan atas pertimbangan karena sekolah ini dalam pembelajarannya menerapkan Full Day School.

\section{Populasi dan Sampel}

\section{Populasi}

Populasi adalah wilayah generalisasi yang terdiri atas: obyek atau subyek yang mempunyai kualitas dan karakteristik tertentu yang ditetapkan oleh peneliti untuk dipelajari dan kemudian ditsrik kesimpulannya. Dalam metode penelitian, kata populasi amat sangat populer, digunakan untuk menyebutkan serumpun atau sekelompok obyek yang menjadi sasaran penelitian. Oleh karenanya, populasi penelitian merupakan keseluruhan dari obyek penelitian yang dapat berupa manusia, hewan, tumbuh-tumbuhan, udara, gejala, nilai, peristiwa, sikap hidup, dan sebagainya, sehingga obyek-obyek ini dapat menjadi data penelitian. ${ }^{3}$

Populasi dalam penelitian ini adalah semua peserta didik di SD Integral Hidayatullah Kota Barat berjumlah 83 orang, terdiri dari:

Kelas 1: 15 Peserta Didik

Kelas 2: 16 Peserta Didik

Kelas 3: 13 Peserta Didik

Kelas 4: 16 Peseta Didik

Kelas 5: 12 Peserta Didik

Kelas 6: 11 Peserta Didik

\section{Sampel}

Sampel adalah bagian dari jumlah dan karakteristik yang dimiliki oleh pupulasi tersebut. Bila populasi besar dan peneliti tidak mungkin mempelajari semua yang ada pada populasi dikarenakan keterbatasan dana, waktu, tenaga maka peneliti menggunakan sampel yang diambil dari populasi itu. Untuk itu sampel yang diambil dari populasi harus betul-betul yang mewakili. ${ }^{4}$ Sampel adalah bagian dari jumlah dan karakteristik yang dimiliki oleh populasi. ${ }^{5}$ Selain itu sampel juga merupakan wakil dari populasi yang diteliti dengan dasar penetapan jumlah sampel sebagai berikut:

Apabila jumlah populasi kurang dari 100, maka yang menjadi sampel adalah keseluruhan dari populasi tersebut, atau yang disebut dengan penelitian populasi,

\footnotetext{
${ }^{2}$ Sugiyonno, Metode Penelitian Manajemen, (Bandung: Alfabeta, 2013), h. 28

${ }^{3}$ Ibid, h 148

${ }^{4}$ Ibid, h. 150

${ }^{5}$ Sugiyono, Metode Penelitian Pendidikan (Pendekatan Kuantitatif, kualitatif, dan R\&D),
} (Bandung: Alfabeta 2009), hal. 118 
sedangkan apabila jumlah populasi lebih dari 100, maka yang menjadi sampelnya adalah $10 \%-15 \%$ atau $20 \%-25 \% .^{6}$

Berdasarkan pendapat diatas, mengingat populasi dalam penelitian ini berjumlah 117 siswa, maka anggota sampelnya diambil dari perhitungan 10 - 15\%. Jadi diperoleh sampelnya yaitu berjumlah 30 siswa dari jumlah keseluruhan.

Melihat jumlah sampel yang bervariasidari setiap kelas I, II, III, IV, V, VI. Maka ditetapkan teknik pengambilan sampelnya dengan menggunakan teknik Proportionate Stratified Random Sampling ${ }^{7}$.berdasarkan perhitungan dengan cara tersebut maka dapat ditentukan jumlah sampelnya setiap kelas pada tabel dibawah ini :

Tabel 2.

\begin{tabular}{|c|c|c|c|c|}
\hline $\mathrm{NO}$ & Kelas & Jumlah Setiap Kelas/Populasi & Sampel & Hasil \\
\hline 1 & Kelas I & 15 Peserta Didik/83 & X 30 & 4 \\
\hline 2 & Kelas II & 16 Peserta Didik/117 & $\mathrm{X} 30$ & 7 \\
\hline 3 & Kelas III & 13 Peserta Didik/117 & X 30 & 4 \\
\hline 4 & Kelas IV & 16 Peserta Didik/117 & X 30 & 7 \\
\hline 5 & Kela5s V & 12 Peserta Didik/117 & X 30 & 4 \\
\hline 6 & Kelas VI & 11 Peserta Didik/117 & $\mathrm{X} 30$ & 4 \\
\hline \multicolumn{4}{|c|}{ Jumlah } & 30 \\
\hline
\end{tabular}

Dari hasil perhitungn dengan menggunkan teknik sampling Proportionate Stratified Random Sampling maka diperoleh 30 peserta didik.

\section{Variabel-variabel Penelitian}

Variabel penelitian adalah suatu atribut atau sifat atau nilai dari orang, objek atau kegiatan yang mempunyai variasi tertentu ditetapkan oleh peneliti untuk dipelajari dan kemudian ditarik kesimpulannya. ${ }^{8}$

Penlitian ini terdiri dari satu variabel bebas dan satu variabel terikat. Definisi penelitian operasional ini adalah:

a) Variabel Bebas $(\mathrm{X})$ yang mempengaruhi dalam penelitian ini adalah penerapan full Day School.

b) Variabel terikat (Y) yang dipengaruhi dalam penelitian ini adalah hasil belajar Pendidikan Agama Islam.

\section{TEHNIK PENGUMPULAN DATA}

\section{Metode Kuesioner (Angket)}

Kuesioner merupakan tehnik pengumpulan data yang dilakukan dengan cara memberi seperangkat pertanyaan atau pernyataan tertulis kepada responden untuk menjawabnya. Kuesioner dalam penelitian ini memuat dua veriabel, yaitu variabel $\mathrm{X}$ (Full Day School) Variabel Y (Hasil Belajar Pendidikan Agama Islam).

${ }^{6}$ Kasiram., Metodologi Penelitian Kualitatif-kuantitatif, (Yogyakarta: UIN Maliki Press, 2010), hal. 257

${ }^{7}$ lbid, h. 118

${ }^{8}$ Ibid, h. 231 
Dalam hal ini, peneliti memberikan pernyataan secara tertulis kepada responden untuk dijawab dengan menggunakan lima alternatif jawaban: sangat setuju (SS), setuju (S), ragu-ragu (RR), tidak setuju (TS), sangat tidak setuju (STS). ${ }^{9}$

Ini merupakan skala likert, skala ini untuk mengukur sikap, pendapat, dan presepsi seseorang atau kelompok orang tentang fenomena sosial. Dalam skala ini saya akan mengambil bentuk checklist.

Contoh: Tabel 3. Contoh pernyataan angket.

\begin{tabular}{|c|c|c|c|c|c|c|}
\hline \multirow{2}{*}{ NO } & \multirow{2}{*}{ PERYATAAN } & \multicolumn{5}{|c|}{ JAWABAN } \\
\hline & & \multirow{2}{*}{\begin{tabular}{|l|l|} 
SS \\
$\checkmark$
\end{tabular}} & \multirow[t]{2}{*}{ ST } & \multirow[t]{2}{*}{$\mathbf{R R}$} & \multirow[t]{2}{*}{ TS } & \multirow[t]{2}{*}{ STS } \\
\hline 1 & $\begin{array}{l}\text { penerapan Full Day Schooll baik untuk diterapkan di } \\
\text { sekolah }\end{array}$ & & & & & \\
\hline 2 & ......... & & & & & \\
\hline $\mathrm{SS}=$ & Sangat Setuju & & & & & \\
\hline $\mathrm{ST}=$ & Diberi Skor 4 & & & & & \\
\hline $\mathrm{RR}=$ & Diberi Skor & & & & & \\
\hline $\mathrm{TS}=$ & Tidak Setuju & & & & & \\
\hline STS & Sangat Tidak Setuju Diberi Skor & & & & & \\
\hline
\end{tabular}

\section{TEHNIK ANALISIS DATA}

\section{Analisis Regresi}

Regresi atau peramalan adalah suatu proses memperikan secara sistematis tentang apa yang paling mungkin terjadi dimasa yang akan datang berdasaran informasi masa lalu dan sekarang yang dimiliki agar kesalhannya dapat diperkecil ${ }^{10}$. regresi juga dapat diartikan sebagai usaha utuk memperkirakan perubahan. Supaya tidak salah paham bahwa peramalan tidak memberikan jawaban pasti tentang apa yang akan terjadi, regresi mengemukaan tentang keingintahuan tentang apa yang terjadi dimasa depan untuk memberikan kontrubusi menentukan keputusan yang terbaik.

Kegunaan regresi dalam penelitian sala satunya adalah untuk meramalkan atau memprediksikan seberapa tinggi nilai variabel terkait (x) yaitu (penerapan Full Day School) Variabel (y) yaitu (hasil belajar Pendidikan Agama Islam) dimanipulasi/diubahubah.

Adapun rumus yang digunakan yaitu:

$(\mathrm{Y}=\mathrm{a}+\mathrm{bx})$

Dinama :

$\mathrm{Y}$; subjek variabel terikat yang diproyeksikan

$X$; variabel bebas yang mempunyai nilai untuk diprediksi

$\mathrm{a}=$ nilai konstanta harga $\mathrm{y}$ jika $\mathrm{x}=0$

$\mathrm{b}=$ koefisien regresi/nilai arah sebagai penentu ramalan (prediksi) yang menunjukan nilai peningkat $(+)$ atau nilai penurunan $(-)$ variabel.

\footnotetext{
${ }^{9}$ Ibid. h. 232

${ }^{10}$ Mujahid Damopolii, Pedoman Karya Tulis Ilmiah Skripsi (Gorontalo:Sultan Amai Pres) H. 162
} 


\section{HASIL PENELITIAN}

\section{Deskripsi Hasil Pengolahan Data}

\section{Pengujian Validitas dan Reliabilitas Kuesioner Variabel $\mathbf{X}$ dan $\mathbf{Y}$}

Hasil pengujian validitas dan reliabilitas untuk masing-masing variabel yang digunakan adalah sebagai berikut :

\section{a) Variabel Fullday School}

Jumlah pertanyaan yang digunakan untuk mengukur Fullday School dalam penelitian ini sebanyak 15 pertanyaan. Hasil pengujian validitas dan reliabilitas 15 pertanyaan tersebut adalah sebagai berikut

Tabel 7. Pengujian Validitas Dan Reliabilitas

\begin{tabular}{|c|c|c|c|c|}
\hline Variabel & Nomor & Nilai $\mathbf{r}$ & r-kritis & Kesimpulan \\
\hline \multirow{15}{*}{ Fullday School } & Item 1 & 0.539 & \multirow{12}{*}{0,37} & Valid \\
\hline & Item 2 & 0.605 & & Valid \\
\hline & Item 3 & 0.589 & & Valid \\
\hline & Item 4 & 0.442 & & Valid \\
\hline & Item 5 & 0.584 & & Valid \\
\hline & Item 6 & 0.594 & & Valid \\
\hline & Item 7 & 0.647 & & Valid \\
\hline & Item 8 & 0.487 & & Valid \\
\hline & Item 9 & 0.663 & & Valid \\
\hline & Item 10 & 0.470 & & Valid \\
\hline & Item 11 & 0.465 & & Valid \\
\hline & Item 12 & 0.562 & & Valid \\
\hline & Item 13 & 0.631 & & Valid \\
\hline & Item 14 & 0.402 & & Valid \\
\hline & Item 15 & 0.550 & & Valid \\
\hline
\end{tabular}

Hasil analisis diatas menunjukkan bahwa dari segi ketepatan dalam mengukur, seluruh pertanyaan yang digunakan dalam mengukur Full Day School telah memiliki ketepatan yang baik.Ini terlihat dari besarnya koefisien validitas yang dihasilkan oleh setiap item pertanyaan yang semuanya diatas 0,37 .

Interpretasi untuk melihat hasil validitas yaitu perhatikan nilai Pearson Correlation. Jika nilai Pearson Correlation > R tabel maka dikatakan valid. Untuk jumlah sampel $=30$, nilai $\mathrm{R}$ tabel dgn tingkat kepercayaan 0,05 adalah 0,278

Adapun hasil pengujian reliabilitas untuk variabel Full Day School adalah sebagai berikut : 
Tabel 8.

Reliability Statistics

\begin{tabular}{|l|l|l|}
\hline & $\begin{array}{l}\text { Cronbach's } \\
\text { Alpha Based } \\
\text { on } \\
\text { Standardized }\end{array}$ & \\
Cronbach's & $\begin{array}{l}\text { Items } \\
\text { Alpha }\end{array}$ & of Items \\
\hline .835 & .835 & 15 \\
\hline
\end{tabular}

Nilai koefisien reliabilitas untuk variabel Full Day School dari hasil diatas adalah sebesar 0,835 . Nilai koefisien reliabilitas ini lebih besar dari 0,5 sehingga menunjukkan hasil pengukuran yang dihasilkan oleh instrumen yang digunakan menunjukkan konsistensi yang cukup baik pada setiap responden. Atau dengan kata lain, persepsi responden mengenai pertanyaan yang digunakan sudah homogen.

\section{b) Variabel Hasil Belajar Pendidikan Agama Islam (PAI)}

Untuk variabel Hasil Belajar, jumlah pertanyan yang digunakan sebanyak 15 pertanyaan. Hasil pengujian validitas dan reliabilitas ke 15 pertanyaan tersebut adalah sebagai berikut :

Tabel 9. Pengujian Validitas Dan Reliabilitas

\begin{tabular}{|c|c|c|c|c|}
\hline Variabel & Nomor & Nilai $\mathbf{r}$ & $\begin{array}{l}\text { r- } \\
\text { kritis }\end{array}$ & Kesimpulan \\
\hline \multirow{15}{*}{$\begin{array}{l}\text { Hasil } \\
\text { PAI }\end{array}$} & Item 1 & 0.447 & \multirow{15}{*}{0,37} & Valid \\
\hline & Item 2 & 0.525 & & Valid \\
\hline & Item 3 & 0.598 & & Valid \\
\hline & Item 4 & 0.522 & & Valid \\
\hline & Item 5 & 0.578 & & Valid \\
\hline & Item 6 & 0.537 & & Valid \\
\hline & Item 7 & 0.467 & & Valid \\
\hline & Item 8 & 0.474 & & Valid \\
\hline & Item 9 & 0.607 & & Valid \\
\hline & Item 10 & 0.645 & & Valid \\
\hline & Item 11 & 0.550 & & Valid \\
\hline & Item 12 & 0.608 & & Valid \\
\hline & Item 13 & 0.487 & & Valid \\
\hline & Item 14 & 0.516 & & Valid \\
\hline & Item 15 & 1.000 & & Valid \\
\hline
\end{tabular}

Hasil analisis di atas menunjukkan bahwa dari segi ketepatan dalam mengukur, seluruh pertanyaan yang digunakan dalam mengukur hasil belajar PAI telah memiliki 
ketepatan yang baik.Ini terlihat dari besarnya koefisien validitas yang dihasilkan oleh setiap item pertanyaan yang semuanya diatas 0,37 .

Interpretasi untuk melihat hasil validitas yaitu perhatikan nilai Pearson Correlation. Jika nilai Pearson Correlation > R tabel maka dikatakan valid. Untuk jumlah sampel $=30$, nilai $\mathrm{R}$ tabel dgn tingkat kepercayaan 0,05 adalah 0,37

Adapun hasil pengujian reliabilitas untuk variabel hasil belajar adalah sebagai berikut :

Tabel 10

Reliability Statistics
\begin{tabular}{|l|l|l|}
\hline & $\begin{array}{l}\text { Cronbach's } \\
\text { Alpha Based } \\
\text { on } \\
\text { Standardized } \\
\text { Items }\end{array}$ & N of Items \\
\hline $\begin{array}{l}\text { Cronbach's } \\
\text { Alpha }\end{array}$ & .825 & 15 \\
\hline .815 & & \\
\hline
\end{tabular}

Nilai koefisien reliabilitas untuk variabel hasil belajar PAI dari hasil diatas adalah sebesar 0,825 . Nilai koefisien reliabilitas ini lebih besar dari 0,5 sehingga menunjukkan hasil pengukuran yang dihasilkan oleh instrumen yang digunakan menunjukkan konsistensi yang cukup baik pada setiap responden. Atau dengan kata lain, persepsi responden mengenai pertanyaan yng digunakan sudah homogen.

\section{HASIL ANALISIS REGRESI}

\section{Pengujian Persyaratan Analisis Data}

Sebelum melakukan analisis data dengan menggunakan regresi, terlebih dahulu dilakukan pengecekan persyaratan analisis

Untuk keperluan ini, akan dilakukan pengujian normalitas data dengan menggunakan uji Kolmogorv-Smirnov (KS) dengan prosedur sebagai berikut :

- Menentukan hipotesis

- Menentukan tingkat signifikansi

- Menentukan statistik uji

- Menentukan kriteria uji

Hasil pengujian normalitas data dengan menggunakan SPSS adalah sebagai berikut: 
Tabel 11.

One-Sample Kolmogorov-Smirnov Test

\begin{tabular}{|ll|l|}
\hline & & $\begin{array}{l}\text { Unstandardize } \\
\text { d Residual }\end{array}$ \\
\hline $\mathrm{N}$ & & 30 \\
Normal Parameters ${ }^{\mathrm{a}}$ & Mean & .0000000 \\
& Std. Deviation & 5.58958387 \\
Most $\quad$ Extreme & Absolute & .078 \\
Differences & Positive & .078 \\
& Negative & -.075 \\
Kolmogorov-Smirnov Z & & .430 \\
Asymp. Sig. (2-tailed) & & .993 \\
\hline
\end{tabular}

Test distribution is Normal.

Hasil analisis diatas menunjukkan nilai koefisien Kolmogorov Smirnov (KS) sebesar 0, 430 dengan nilai signifikansi sebesar 0,993.Jika dibandingkan dengan nilai apha yang digunakan $(0,05)$ maka nilai signifikansi ini masih lebih besar dari alpha sehingga Ho diterima. Dengan demikian dapat disimpulkan bahwa data variabel dependen hasil belajar PAI telah berdistribusi normal.

Kesimpulan dari pengujian ini juga didukung dengan hasil plot data yang menunjukkan bahwa data dari variabel hasil belajar menyebar di sekitar garis lurus seperti yang tampak dalam grafik berikut ini :

Normal P-P Plot of Regression Standardized Residual

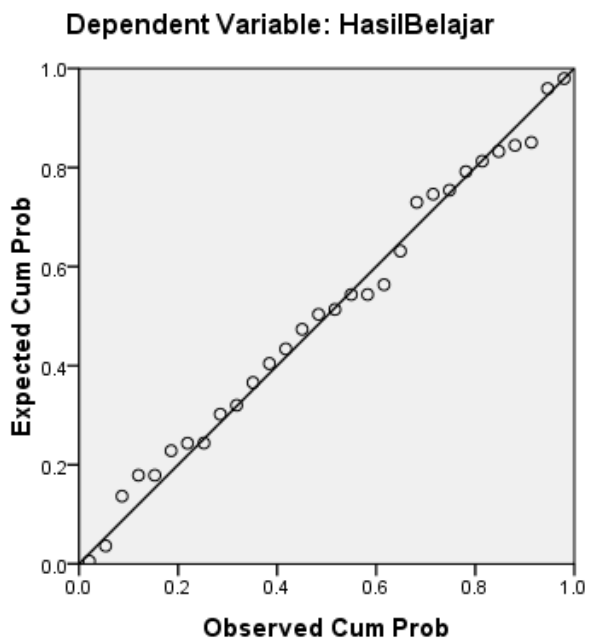

Gambar 2. 
Gambar diatas menjelaskan bahwa seluruh titik-titik yang berada pada grafik tersebar mengikuti garis diagonal. Pengujian normalitas berdasarkan grafik pp-plot adalah:

a) Jika data menyebar di sekitar garis diagonal dan mengikuti arah garis diagonal maka model regresi memenuhi asumsi normalitas.

b) Jika data menyebar jauh dari garis diagonal dan atau mengikuti arah garis diagonal maka model regresi tidak memenuhi asumsi normalitas.

Berdasarkan penyataan diatas, maka dapat disimpulkan bahwa sebaran data (instrumen) yang digunakan pada penelitian ini terlah terdistribusi secara normal. Hal tersebut berarti langkah-langkah yang digunakan sebagai syarat pengujian regresi telah terpenuhi sehingga dapat dilanjutkan pada pengujian berikutnya Dengan Histogram sebagai berikut:

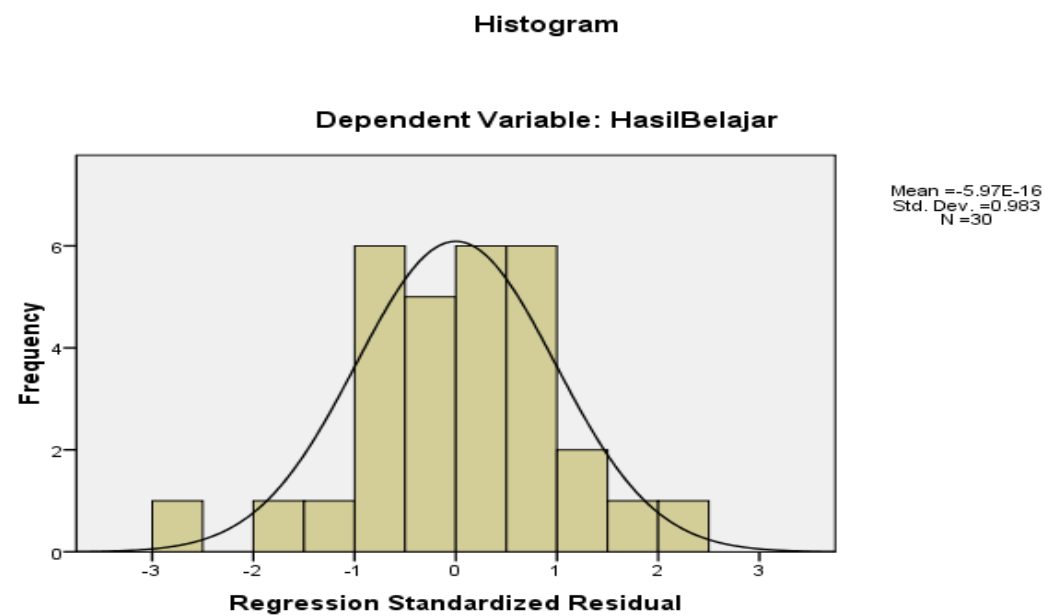

Gambar 3

\section{Model Analisis Regresi}

Hasil analisis regresi yang diperoleh dengan menggunakan bantuan SPSS adalah sebagai berikut :

Tabel 12.

\section{Coefficients $^{\mathrm{a}}$}

\begin{tabular}{|c|c|c|c|c|c|c|}
\hline \multirow{2}{*}{\multicolumn{2}{|c|}{ Model }} & \multicolumn{2}{|c|}{ Unstandardized Coefficients } & \multirow{2}{*}{\begin{tabular}{|l}
$\begin{array}{l}\text { Standardized } \\
\text { Coefficients }\end{array}$ \\
Beta
\end{tabular}} & \multirow[b]{2}{*}{$\mathrm{T}$} & \multirow[b]{2}{*}{ Sig. } \\
\hline & & B & Std. Error & & & \\
\hline 1 & (Constant) & 18.197 & 8.713 & & 2.089 & .046 \\
\hline & FulldaySchool & .715 & .139 & .696 & 5.129 & .000 \\
\hline
\end{tabular}

a. Dependent Variable: HasilBelajar

Berdasarkan hasil analisis diatas maka model regresi antara Full Day School dengan hasil belajar adalah sebagai berikut:

$$
\mathrm{Y}=18.197+0.715 \mathrm{X}
$$

Dari hasil diatas dapat diinterpretasikan beberapa hal berikut : 
- Tanda koefisien regresi untuk variabel $\mathrm{X}$ yang negatif menunjukkan terdapat pengaruh yang positif dari Fullday School (X) terhadap Hasil Belajar (Y).

- Semakin baik Full Day School memberikan dampak terhadap peningkatan hasil belajar. Setiap peningkatan Full Day School sebesar satu satuan akan meningkatkan hasil belajar sebesar 0,715 satuan.

\section{Pengujian Model Regresi}

Pengujian model regresi ini dilakukan dengan menggunakan uji $\mathrm{F}$ dengan tahapan sebagai berikut :

1) Penentuan Hipotesis

Ho: seluruh koefisien regresi tidak signifikan (model regresi tidak signfikan)

H1: minimal satu koefisien regresi signifikan (model regresi signfikan)

2) Penentuan tingkat signifikansi

Tingkat kepercayaan yang akan digunakan dalam penelitian ini adalah sebesar 95\% atau dengan kata lain tingkat signfikansinya (alpha) sebesar 5\%

3) Penentuan Statistik Uji

Dalam melakukan uji kebaikan model digunakan uji F.

4) Penentuan Kriteria uji

Penentuan kriteria uji didasarkan pada perbandingan antara nilai F-hitung yang diperoleh dengan F-tabel. Jika nilai F-hitung lebih besar dari F-tabel maka Ho ditolak, dan jika nilai F-hitung lebih kecil dari nilai F-tabel maka Ho diterima

Hasil pengujian dengan menggukan SPSS adalah sebagai berikut:

Tabel 13.

ANOVA $^{b}$

\begin{tabular}{|ll|ll|l|l|l|l|}
\hline \multicolumn{2}{|l|}{} & $\begin{array}{l}\text { Sum } \\
\text { Model }\end{array}$ & Squares & Df & Mean Square & F & Sig. \\
\hline 1 & Regression & 851.307 & 1 & 851.307 & 26.308 & $.000^{\mathrm{a}}$ \\
& Residual & 906.060 & 28 & 32.359 & & \\
& Total & 1757.367 & 29 & & & \\
\hline
\end{tabular}

a. Predictors: (Constant), Full daySchool

b. Dependent Variable: HasilBelajar PAI

Dari hasil analisis di atas dapat diketahui nilai F-hitung untuk model regresi antara Fullday School dengan Hasil Belajar adalah sebesar 26,308 dengan nilai signifikansi sebesar 0,000. Jika dibandingkan dengan nilai alpha sebesar 0,05 maka nilai signifikansi ini jauh lebih besar dari nilai alpha sehingga Ho diterima. Dengan demikian dapat disimpulkan bahwa model regresi yang dibangun telah sesuai dengan data. Didapatkan nilai sig $=0,000(\mathrm{p}>0,05)$ artinya Full Day School tidak memiliki pengaruh yang signifikan terhadap hasil belajar PAI.

\section{INTERPRETASI DATA}

Setelah pengujian model dilakukan selanjutnya akan dilaksanakan pengujian signfikansi pengaruh dari tingkat Full Day School terhadap hasil belajar PAI. Adapun pengujian yang akan dilakukan adalah sebagai berikut : 
1. Penentuan Hipotesis

Ho : tidak terdapat pengaruh positif dari Full Day School terhadap hasil belajar

H1 : terdapat pengaruh positif dari Full Day School terhadap hasil belajar

2. Penentuan tingkat signifikansi

Tingkat kepercayaan yang akan digunakan dalam penelitian ini adalah sebesar 95\% atau dengan kata lain tingkat signfikansinya (alpha) sebesar 5\%.

3. Penentuan Statistik Uji

Dalam melakukan uji signfikansi pengaruh dalam model regresi akan digunakan uji t.

4. Penentuan Kriteria uji

Penentuan kriteria uji didasarkan pada perbandingan antara nilai t-hitung yang diperoleh dengan t-tabel. Jika nilai t-hitung lebih besar dari t-tabel maka Ho ditolak, dan jika nilai t-hitung lebih kecil dari nilai t-tabel maka Ho diterima Hasil pengujian dengan menggukan SPSS adalah sebagai berikut :

Tabel 14. Coefficients ${ }^{\mathrm{a}}$

Coefficients $^{\mathrm{a}}$

\begin{tabular}{|ll|l|l|l|}
\hline \multirow{2}{*}{ Model } & & \multirow{2}{*}{$\begin{array}{l}\text { Standardized } \\
\text { Coefficients }\end{array}$} & \\
\cline { 2 - 3 } & Beta & $\mathrm{T}$ & Sig. \\
\hline 1 & (Constant) & & 2.089 & .046 \\
& FulldaySchool & .696 & 5.129 & .000 \\
\hline
\end{tabular}

a. Dependent Variable: HasilBelajar

a) Dependent Variable: HASIL BELAJAR

Dari hasil analisis di atas diketahui nilai t-hitung untuk variabel Full Day School adalah sebesar 5,129 dengan nilai signifikansi sebesar 0.000. Nilai signifikansi ini masih lebih besar dari nilai alpha $(0,05) \mathrm{H}_{0}$ diterima dan Ha di tolak. Dengan kata lain pada tingkat kepercayaan $95 \%$ dapat disimpulkan bahwa terdapat pengaruh yang signifikan dari Fullday School terhadap Hasil Belajar.

Setelah diketahui bahwa terdapat pengaruh negatif dari Fullday School terhadap Hasil Belajar maka langkah selanjutnya adalah menganalisis besar pengaruh yang ditimbulkan oleh Fullday School terhadap Hasil Belajar peroleh. Untuk keperluan tersebut digunakan analisis koefisien determinasi.

Nilai koefisien determinasi merupakan suatu nilai yang besarnya berkisar antara $0 \%-100 \%$.Semakin besar nilai koefisien determinasi suatu model regresi menunjukkan bahwa pengaruh dari variabel bebas yang terdapat dalam model terhadap variabel tak bebasnya juga semakin tinggi.

Hasil perhitungan koefisien determinasi untuk model regresi antara Full Day School dengan Hasil Belajar adalah sebagai berikut: 
Tabel 15

Model Summary
\begin{tabular}{|l|l|l|l|l|}
\hline Model & $\mathrm{R}$ & R Square & $\begin{array}{l}\text { Adjusted } \\
\text { Square }\end{array}$ & $\begin{array}{l}\text { Rtd. Error of } \\
\text { the Estimate }\end{array}$ \\
\hline 1 & $.696^{\mathrm{a}}$ & .484 & .466 & 5.689 \\
\hline
\end{tabular}

Gambar14. a. Predictors: (Constant), Full day

School

b. Dependent Variable: HasilBelajar

Dari analisis diatas terlihat Didapatkan $\mathrm{R}$ Square $=0,484$ Artinya bahwa variabel independen yg diteliti memiliki pengaruh kontribusi sebesar $48,4 \%$ terhadap variabel hasil belajar, sedangkan 51,6\% lainnya dipengaruhi oleh faktor-faktor lain diluar variabel yg diteliti. Nilai ini berarti bahwa variasi hasil belajar di SD Integral Hidayatullah Kota Barat tergantung baik buruknya full day School.

\section{PEMBAHASAN}

Pada bagian ini akan dikemukakan pembahasan hasil penelitian yang mengacu ada pokok permasalahan, dan hasil analisis dekriptif dan hipotesis sebagaimana yang telah diuraikan pada bagian sebelumnya.Yang pertama peneliti melakukan uji validitas dan reabilitas. Hasil dari uji validitas adalah terterima, sebab variabel Full Day School dan variabel hasil belajar PAI menunjukan diatas standar nilai yang sesuai degan rumus statistika yaitu 0,37. Dan Nilai koefisien reliabilitas untuk variabel Full Day School dari hasil diatas adalah sebesar 0, 835. Dan untuk variabel hasil belajar adalah 0, 825. Nilai koefisien reliabilitas ini lebih besar dari 0,5 sehingga menunjukkan hasil pengukuran yang dihasilkan oleh instrumen yang digunakan menunjukkan konsistensi yang cukup baik pada setiap responden. Sebelum melakukan analisis data dengan menggunakan regresi, terlebih dahulu dilakukan pengecekan persyaratan analisis.

Untuk keperluan ini, akan dilakukan pengujian normalitas data dengan menggunakan uji Kolmogorv-Smirnov (KS) dengan prosedur sebagai berikut :

- Menentukan hipotesis

- Menentukan tingkat signifikansi

- Menentukan statistik uji

- Menentukan kriteria uji

Hasil pengujian normalitas data dengan menggunakan SPSS adalah sebagai berikut:

Hasil analisis adalah menunjukkan nilai koefisien Kolmogorov Smirnov (KS) sebesar 0, 430 dengan nilai signifikansi sebesar 0,993.Jika dibandingkan dengan nilai apha yang digunakan $(0,05)$ maka nilai signifikansi ini masih lebih besar dari alpha sehingga Ho diterima. Dengan demikian dapat disimpulkan bahwa data variabel dependen hasil belajar PAI telah berdistribusi normal. Kemudian peneliti melakukan pengujian analisis regresi, hasil analisis regresi yang diperoleh dengan menggunakan bantuan SPSS adalah sebagai berikut : 
Berdasarkan hasil analisis maka model regresi antara Full Day School dengan hasil belajar PAI adalah sebagai berikut:

$$
\mathrm{Y}=\mathbf{1 8 . 1 9 7}+\mathbf{0 . 7 1 5 X}
$$

Ini menunjukan bahwa semakin baik Full Day School memberikan dampak terhadap peningkatan hasil belajar. Setiap peningkatan Full Day School sebesar satu satuan akan meningkatkan hasil belajar sebesar 0,715 satuan. Kemudian pengujian model regresi ini dilakukan dengan menggunakan uji $\mathrm{F}$ dengan tahapan sebagai berikut : Dari hasil analisis dapat diketahui nilai F-hitung untuk model regresi antara Full Day School dengan Hasil Belajar adalah sebesar 26,308 dengan nilai signifikansi sebesar 0,000. Jika dibandingkan dengan nilai alpha sebesar 0,05 maka nilai signifikansi ini jauh lebih besar dari nilai alpha sehingga Ho diterima. Dengan demikian dapat disimpulkan bahwa model regresi yang dibangun telah sesuai dengan data. Didapatkan nilai sig $=0,000(\mathrm{p}>0,05)$ artinya Full Day School tidak memiliki pengaruh yang signifikan terhadap hasil belajar PAI.

Setelah pengujian model dilakukan selanjutnya akan dilaksanakan pengujian signfikansi pengaruh dari tingkat Full Day School terhadap hasil belajar PAI. Adapun pengujian yang akan dilakukan adalah sebagai berikut : Dari hasil analisis diketahui nilai t-hitung untuk variabel Full Day School adalah sebesar 5,129 dengan nilai signifikansi sebesar 0.000. Nilai signifikansi ini masih lebih besar dari nilai alpha $(0,05) \mathrm{H}_{0}$ diterima dan Ha di tolak. Dengan kata lain pada tingkat kepercayaan $95 \%$ dapat disimpulkan bahwa terdapat pengaruh yang signifikan dari Fullday School terhadap Hasil Belajar PAI.

Setelah diketahui bahwa terdapat pengaruh negatif dari Fullday School terhadap Hasil Belajar PAI maka langkah selanjutnya adalah menganalisis besar pengaruh yang ditimbulkan oleh Full Day School terhadap Hasil Belajar PAI peroleh. Untuk keperluan tersebut digunakan analisis koefisien determinasi. Nilai koefisien determinasi merupakan suatu nilai yang besarnya berkisar antara 0\% - 100\%.Semakin besar nilai koefisien determinasi suatu model regresi menunjukkan bahwa pengaruh dari variabel bebas yang terdapat dalam model terhadap variabel tak bebasnya juga semakin tinggi.

Kemudian hasil perhitungan koefisien determinasi untuk model regresi antara Full Day School dengan Hasil Belajar PAI adalah sebagai berikut: dari analisis terlihat Didapatkan R Square $=0,484$ Artinya bahwa variabel independen yg diteliti memiliki pengaruh kontribusi sebesar 48,4\% terhadap variabel hasil belajar, sedangkan 51,6\% lainnya dipengaruhi oleh faktor-faktor lain diluar variabel yg diteliti. Nilai ini berarti bahwa variasi hasil belajar di SD Integral Hidayatullah Kota Barat tergantung baik buruknya full day School.

Sekolah dengan sistem Full Day School adalah bentuk satuan pendidikan yang diselenggarakan berdasarkan kurikulum Kemendiknas dan ditambah dengan kurikulum kemenag. Model yang dikembangkan adalah pengintegrasian antara pendidikan agama dan umum dengan memaksimalkan perkembangan aspek kognitif, afektif serta psikomotorik. Proses belajar mengajarnya diberlakukan dari pagi sampai sore yang dimulai dari pukul 06.40 pagi sampai 15.40 sore. Dalam full day school, kegiatankegiatan belajar seperti tugas sekolah yang biasanya dikerjakan di rumah dapat dikerjakan di sekolah dengan bimbingan guru yang bertugas. Namun bukan berarti Full Day School mengekang siswa untuk tidak bermain dan terus menerus belajar, tetapi 
dalam Full Day School juga terdapat metode dan media belajar yang meliputi kelas dan alam sehingga siswa tidak menjadi bosan. Dengan adanya sistem full day school, lamanya waktu pembelajaran tidak menjadi beban karena sebagian waktunya digunakan untuk waktu-waktu informal.

Berdasarkan hasil penelitian, diperoleh kesimpulan bahwa Full Day School menjadi faktor yang mempengaruhi hasil belajar. dengan nilai mencapai sebesar 48,4\% terhadap variabel hasil belajar, sedangkan 51,6\% lainnya dipengaruhi oleh faktor-faktor lain diluar variabel yg diteliti. Dengan demikian dapat dipastikan bahwa tanpa adanya Full Day School yang baik dapat berakibat pada meningkatnya hasil belajar di SD Integral Hidayatullah Kota Barat, lembaga pendidikan ini, awal pembentukkan penerapan sistem Full Day School didasarkan oleh beberapa faktor yaitu: (a)Tingginya kemauan dari siswa untuk bersekolah di wilayah ini. Tetapi pada kenyataannya menunjukkan bahwa terbatasnya jumlah Sekolah Dasar berbasis Islam yang berada di wilayah ini. (b)Minimnya lembaga selain sekolah reguler yang dapat memenuhi kepuasan pelanggan/orang tua/masyarakat, baik dari sisi prestasi akademik maupun prestasi akhlak. Dari beberapa faktor pembentukkan penerapan sistem Full Day School tersebut, akhirnya pada tahun 2012 sekolah ini berdiri dan menerapkan sistem Full Day School yang dianggap mampu menjawab keinginan orang tua khususnya dan masyarakat pada umumnya.

Meskipun baru menerapkan sistem Full Day School selama kurang lebih 6 tahun, namun terdapat inovasi-inovasi yang menarik pada sekolah ini. Selain itu sekolah tersebut juga mengoptimalkan penerapan sistem Full Day School dengan menggabungkan antara kurikulum nasional dengan kurikulum yang dibuat sendiri oleh sekolah tersebut yaitu dengan menambah jadwal-jadwal yang bersifat keagamaan seperti mengaji, imlak, shalat berjama'ah dan lain-lain. Setelah diterapkannya sistem Full Day School di sekolah tersebut dengan berbagai inovasi-inovasi yang telah ada. Seiring berjalannya waktu, sekolah ini semakin banyak peminat karena dapat memberikan bukti bahwa sekolah ini layak untuk bersaing dengan sekolah umum lainnya.

Pada akhirnya dapat dikemukakan bahwa variabel bebas yang di analisis yaitu terdapat pengaruh yang positif dan signifikan antara Full Day School terhadap hasil belajar di SD Integral Hidayatullah Kota Barat.

\section{PENUTUP}

\section{Kesimpulan}

Berdasarkan hasil penelitian, maka dapat diambil kesimpulan sebagai berikut:

1. Hipotesis statistik yang disusun diterima dimana $\mathrm{H}_{1}$ ditolak dan $\mathrm{H}_{\mathrm{o}}$ diterima, atau Full Day School memiliki pengaruh terhadap hasil belajar di SD Integral Hidayatullah Kota Barat.

2. Besarnya pengaruh Full Day School yang dilakukan SD Integral Hidayatullah Kota Barat yaitu sebesar $48,4 \%$ terhadap hasil belajar PAI. Hal tersebut menjadikan kegiatan Full Day School yang dilakukan menjadi faktor utama tolak ukur hasil belajar PAI. Adapun faktor lainnya yang mempengaruhi hasil belajar sebesar 51,6\%. 


\section{Saran}

Dari hasil penelitian, ada beberapa saran yang dapat diajukan disini yaitu antara lain:

1. Bagi Sekolah

2. Hendaknya guru lebih berkompeten dalam memberikan petunjuk, pengarahan, kontrol pembinaan secara kondusif terhadap siswa dalam sistem belajar mengajar bagi keberhasilan belajar siswa dengan menggunakan berbagai macam pendekatan dan pola pengajaran.

3. Bagi Siswa

4. Siswa diharapkan tetap bersemangat dalam belajar. Dengan menjadi dirinya sendiri dengan kemampuan dan segala potensi yang dimilikinya, siswa akan dapat menetapkan langkah positif demi meraih cita-cita kelak, maka siswa harus dapat memotivasi dirinya sendiri untuk lebih giat dan rajin dalam belajar.

5. Bagi Orang Tua

6. Hendaknya orang tua berpartisipasi dalam pembinaan dan pengarahan, agar siswa terarah secara positif dan kontributif dalam belajar anaknya demi keberhasilan belajar dan meningkatkan hasil belajarnya.

7. Bagi Peneliti yang akan datang

8. Hendaknya bagi peneliti lanjutan yang meneliti tentang pengaruh Full Day School terhadap hasil belajar, hendaknnya lebih mengembangkan lagi variabel bebasnya untuk memperoleh hasil penelitian yang maksimal.

\section{DAFTAR PUSTAKA}

Al-Qur'an, Departemen Agama RI (Klaten: PT Mencana Jaya Cemerlang 2008)

Baharuddin, Pendidikan dan Psikologi Perkembangan, Jogjakarta: Ar-Ruzz media, 2016

Soleha dan Rada, Ilmu Pendidikan Islam, Bandung: Alfabeta, 2011

Rois Mahmud, Al-Islam Pendidikan Agama Islam, Jakarta: Erlangga, 2011

Syed Mahmudunnasir, Islam Konsepsi Dan Sejarahnya, Bandung: Remaja Rosdakarya, 2010

Yoyon Bahtiar Irianto, Kebijakan Pembaharuan pendidian konsep, teori dan model Jakarta: Raja Grafindo, 2011

Daryanto, \& Darmiatun, Suyatri Implementasi Pendidikan Karakter di Sekolah.(Yogyakarta, Gava Media, 2013).

Mahmud, Rois. Al-Islam Pendidikan Agama Islam Jakarta: Erlangga, 2011.

Najamuddin, Pengembangan Materi Pendidikan Agama Islam, Yogyakarta:Teras 2014.

Ramayulis, Dasar-Dasar Kependidikan, Jakarta: Kalam Mulia, 2015.

Sugiyonno, Metode Penelitian Manajemen, Bandung: Alfabeta, 2013.

Nor Hasan, Full Day School, Model Alternatif Pembelajaran Bahasa Asing. Tadris, Jurnal Pendidikan Islam, 2006

Muhibbin Syah, Psikologi Belajar, Jakarta: Bumi Aksara, 2011

M. Alisuf Sabri, Psikologi Pendidikan, Cet.5, Jakarta: Pedoman Ilmu Jaya, 2010. 


\section{Website}

Addin Arsyadana, Penerapan Sistem Full day school Sebagai Upaya UntukMeningkatkanKualitasPendidikan,dalamhttp://lib.uinmalang.ac.id/files/th esis/fullchapter/0611020 6.pdf,

Setiawan, Beni. Menggugat Sekolah Sehari Penuh, 2006 (online) available http://www.fulldayschool.com. Di akses tanggal 08 Mei 2017

Yogabowoleksono.Blogspot.Co.Id/2017/01/Kti-Tentang-Full School.Html. Di Akses Tanggal 05 Mei 2017

http://qurrrotaayun.blogspot.co.id/2013/06/sistem-pendidikan-fulldschool-dan.html http://aceh.tribunnews.com/2017/07/25/menyikapi-kebijakan-full-daschool https://www.kompasiana.com/komitel/pendapatkebijakan_5940e6f24f7a61220cb5d817 https://blog.ruangguru.com/pro-dan-kontra-konsep-full-day-schindonesia. https://nasional.kompas.com/read/2016/08/09/12463051/kpai.anggap.full.day.school.akan .ganggu.kehidupan.sosial.anak.

http://ejournal.sunan.ampel.ac.id/index.php/antologi/article/view/318/257

http://www.beritasatu.com/kesra/447180-ini-pandangan-presidemengenai-full-dayschool.html.

http://suhailayanti.blogspot.co.id/2011/10/analisis-materi-pai-sd.html https://iwankuswandi.wordpress.com/full-day-school-dan-pendiditerpadu/, 